а людей в них то ж. А вытми пашни пахоные худые земли за доброю землю с наддачею выть с четвертью да перелогом пашни выть без четверти» ${ }^{17}$. В описании поселений «толоконџевских бортников» в Заволжье и всех «мордовских сел» пашня в четвертях также указана на деревню, а не подворно. Пересчет в выти осушествлен лишь для Толоконџевской волости в џелом («А вытми пять вытей, а положено тое худые земли на выть по 16 чети» $\left.{ }^{18}\right)$. В дозоре же «мордовских» земель лексема «выть» вообше не встречается. Все это представляется маловероятным, если бы дозоршикам наказом вменялось проведение описания, которое в историографии принято называть «подворно-вытным».

Таким образом, сформулированный в предисловии к публикаџии дозорных книг В. Ф. Борисова и подьячего Третьяка Аврамова 1587/1588 г. тезис о том, что ими «при описании отдельных крестьянских дворов учитывались размеры облагаемой земли в вытях» [Анпилогов, с. 6], является ошибочным. Распределение «пашни паханой» по тяглым дворам, даже ими же вновь выявленной, в компетенџию писџов - в отличие, например, от дозоров дворџовых земель второго десятилетия XVII в. - не входило, оставаясь прерогативой крестьянского мира. Следовательно, говорить о подворно-вытном характере данного описания нет оснований. По-видимому, это справедливо и для дозора дворџовых волостей Каширского уезда 1588/1589 г.

\title{
Литература
}

Анпилогов Г. Н. Нижегородские документы XVI века (1588-1600 гг.). М., 1977.

Дегтярев А. Я. Русская деревня в XV-XVII веках. Очерки истории сельского расселения. М., 1980. Колычева Е. И. Аграрный строй России XVI в. М., 1987.

Natalia V. Sokolova

Institute of Slavic Studies of the Russian Academy of Sciences, Moscow, Russia

\section{ON THE NATURE OF CENSI IN THE 1580s: SOURCES AND METHODS OF SCRIBES}

The article is dedicated to the sources of the Nizhny Novgorod Uezd census books by V. F. Borisov and podyachy Tretyak Avramov $(1587 / 1588)$ and to the methods of the scribes' activities. The analysis showed that the "old books" in the text were the extracts from Peter Burunov's cartulary ("pripravochnye”) books (1577/1578). Another source of description was peasants' skaski. The peculiarities of their use by scribes predetermined the presence of various chronological strata of information in the text, both retrospective and related to the second half of the 1580s. The study shows that there is no reason to speak of the by-household nature of this description.

Keywords: census books, "skaski”, “arable land”, lot, peasants, Nizhny Novgorod Uezd.

17 Там же. ᄉ. 27 об.-28.

18 Там же. $\mathcal{1} .82-82$ об.

УДК 94 ББК 63.3(2)45 DOI 10.25986/IRI.2019.75.1.0027

П. С. Стефанович

Национальный исследовательский университет «Высшая школа

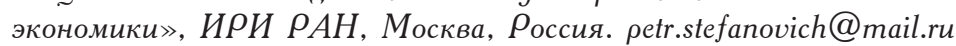

\section{ОСНОВАНИЕ МОСКВЫ ОЛЕГОМ И ХРОНОГРАФ ПАХОМИЯ}

В статье обрашается внимание на особую редакџию текста, известного в науке после публикаџии М. А. Салминой 1964 г. как «Предание об основании Москвы Олегом». Эта редакция содержится в так называемом «Хронографе Пахомия», составленном в 1649-1650 г. Считая эту редакџию первичной, автор заключает, что сам текст (легендарный по содержанию) отражал новые тенденџии историографии XVII в., озабоченной поисками самобытных древних корней русского народа.

Ключевые слова: история, Россия, Москва, летописи, хронографы

В статье пойдет речь об одном эпизоде историографии, посвященной истории Москвы. Уважаемому юбиляру близка «московская» тема (см., например: [Горский]), хотя его интересы лежат скорее в области Средневековья, а в данном случае эта тема раскрывается в контексте истории общественной мысли России середины XVII в.

Как известно, в середине - второй половине XVII в. в русской литературе появились и быстро получили широкое распространение оригинальные произведения о древнейшей истории города Москвы. Џентральным их сюжетом было «зачало», то есть основание, города, и главными героями были князья Владимиро-Суздальской Руси XII-XIII в., деятельность которых была так или иначе связана с ним, - Юрий Долгорукий, Андрей Боголюбский, Даниил, родоначальник московской ветви Рюриковичей. Всего известно три таких произведения. В 1960-е годы М. А. Салмина осушествила их исследование и публикаџию (образџовые для своего времени) ${ }^{1}$.

Древнейшим является, видимо, сочинение, спеџиально посвященное возникновению столиџы Русского государства, - «О зачале џарствуюшаго великаго града Москвы, како исперва зачася», или, как оно кратко

${ }^{1}$ Повести о начале Москвы / Исследование и подг. текстов М. А. Салминой. М.; ․, 1964. 


\section{П. С. Стефранович}

называется в научной литературе, «Повесть о зачале Москвы»². Этот текст представляет собой выборку летописных статей, относящихся к ранней истории Москвы, с введением, где автор обосновывает обращение к этой теме, и рассказом о череде казней и убийств в правление Юрия Долгорукого и Андрея Боголюбского. Произведение, создание которого М. А. Салмина относила ко второй четверти XVII в., дошло до настояџего времени в 30 списках, причем одна копия происходит из патриаршего свода начала 1670 -х годов.

На основе «Повести» в третьей четверти XVII в. было составлено уже совершенно легендарное и оторванное от летописи сочинение, начинающееся с фразы «И почему было Москвђ џарством быть, и хто то знал, что Москвђ государством слыть?» (возможно, это было собственно его заглавие) и известное в науке под условным названием «Сказание об убиении Даниила Суздальского и о начале Москвы»³. Приблизительно тогда же было создано «Сказание о зачатии Москвы и Крутиџкой епископии», в котором сообџение об основании Москвы (здесь приписанном князю Даниилу) было «вплетено» в рассказ об учреждении Крутиџкой (Сарской и Подонской) епархии с подворьем в предместье Москвы.

С 1670-х годов в русскую книжность стали проникать ученые этимологии названия города, которые были распространены с XVI в. в польской, а затем украинской историографиях. Польские историки производили слово Москва от библейского персонажа Мосоха (Мешеха), сына Иафета, внука Ноя, и даже считали этого Мосоха «прародителем» славянских народов [Робинсон, с. 103-119; Мыльников, c. 21-44]. Эта этимология и идея о «прародительстве» Мосоха вошли в украинскую историографию, в частности в «Синопсис», который за несколько лет вышел в нескольких изданиях (1-е изд.: 1674 г., 3-е, наиболее полное: 1680 г.) и быстро приобрел большую популярность в России. В конџе XVII в. о Мосохе уже писали и в собственно русской исторической литературе (часто прямо ссылаясь на «Синопсис»), иногда сочетая его так или иначе с сюжетами из повестей о «зачале» Москвы и предлагая новые этимологии.

В приложении к указанной работе М. А. Салмина опубликовала относительно небольшую летописную статью, где основание Москвы приписано Олегу, «вельможе» первых русских князей Рюрика и Игоря, с явной целью выставить Москву таким же древним городом, как Новгород и Киев ${ }^{5}$. Исследовательниџа указала четыре списка этой статьи из разных летописных сборников конџа XVII в. Статья датирована 6388 (880) г. и в двух списках входит в состав летописей с изложением истории Руси, а в двух списках скопирована отдельно. М. А. Салмина дала статье условное название «Предание об основании Москвы Олегом». Вместе с тем в сноске она отметила, что, в сущности, то же известие «с легендой о построении Москвы Олегом» содержится и в еше некоей «группе поздних летописей» (она указала шесть «летописџев» конџа XVII в.), но текст здесь отличается тем, что Олег выставлен не вельможей, а самостоятельным князем, действуюшим в пору малолетства Игоря.

По справедливому заключению М. А. Салминой, это отличие объясняется тем, что разные книжники ориентировались на разные летописные традиџии - одну, которая восходила к новгородскому летописанию и, вслед за сохранившимся в этой традиџии «Начальным сводом», знала Олега как воеводу Игоря, и другую, которая имела в основе «Повесть временных лет» (далее - ПВЛ), знавшую Олега как самостоятельного князя ${ }^{6}$. Однако остается неясным, почему исследовательниџа не опубликовала в качестве особой редакџии текст «Предания» (коль скоро его вообще можно считать отдельным произведением) с указанием об Олеге как князе.

Не вполне ясным из работы М. А. Салминой остается и решение вопроса, когда было создано «Предание». Фактически она ограничивается указанием на 1698 г., которым датированы две летописи, содержашие статью 6388 г., как terminus ante quem, а с другой стороны, присоединяется к мнению М. О. Скрипиля, что статья могла быть написана «не ранее 60-х годов XVII века». М. О. Скрипиль исходил из мысли, что автор легенды, приписывая основание Москвы Олегу, который захватил и Киев для Игоря, хотел показать, «что Москва и Киев находились в одних руках родоначальника всех русских князей, потомком которого в XVII веке оказался только один русский џарь»; «политическая тенденџия» выразилась «в форме исторической легенды», - писал М. О. Скрипиль, имея в виду русско-польскую войну за Украину, закончившуюся Андрусовским перемирием

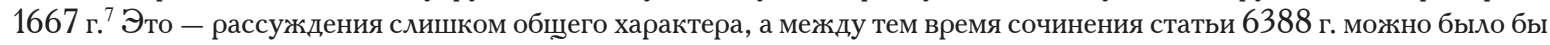
уточнить, разобравшись в разных ее редакџиях и текстологическом взаимоотношении летописно-хронографических сводов, ее содержаших.

Таким образом, работа М. А. Салминой дала в руки исследователей публикаџию одной из редакџий летописной статьи об основании Москвы Олегом, но оставила ряд вопросов об истории этого текста открытыми. В данном случае я хотел бы указать на еше один памятник, который содержит ту же самую статью, но в другом виде и датировка которого заставляет пересмотреть заключения М. О. Скрипиля и М. А. Салминой.

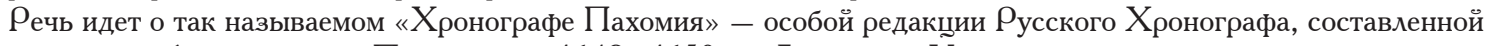
архиепископом Астраханским Пахомием в 1649-1650 г. Датировка Хронографа не вызывает сомнений изза сообшения самого Пахомия, а все древнейшие списки этого Хронографа 1650-1660-х годов включают эту

\footnotetext{
2 См. текст нескольких редакџий «Повести»: Повести о начале Москвы. С. 173-198; о происхождении первоначальной редакции см. в исследовательской части книги: с. $30-35,44-81$.

3 Там же. С. 199-244.

${ }_{4}$ Там же. С. 245-252.

5 Там же. C. 259

6 Ср.: Новгородская первая летопись старшего и младшего изводов. М.-ᄉ., 1950. С. 107; ПСРЛ. ․, 1926. Т. 1. Стб. 22-24.

7 Русская повесть XVII века / Сост. М. О. Скрипиль. Л., 1954. С. 382.
} 
статью 6388 г., так что не приходится сомневаться, что она содержалась в протографе. Как текст, принадлежаший первоначальному авторскому виду Хронографа, рассматривает «Предание» М. А. Савинов, который в недавней работе систематизировал более 20 списков, содержаших текст этого Хронографа полностью или частично [Савинов, c. 86-87].

К сожалению, М. А. Савинов, хотя даже привел текст сообщения об основании Москвы по древнейшему и лучшему списку Хронографа Пахомия (РНБ. ОСРК. F.IV.600), обошел стороной вопрос о разных вариантах этого текста. Между тем из сравнения статьи по спискам Хронографа и по списку, опубликованному М. А. Салминой, становится ясно, что, во-первых, мы имеем дело, действительно, с разными редакџиями и, во-вторых, редакџия Хронографа является первичной. Сопоставим ключевой пассаж статьи 6388 г. по Хронографу и по публикаџии в «Повестях о начале Москвы»:

\begin{tabular}{|c|c|}
\hline $\begin{array}{c}\text { Хронограф Пахомия } \\
\text { (РНБ. ОСРК. F.IV.600. Л. } 543 \text { об.) }\end{array}$ & $\begin{array}{c}\text { Повести о начале Москвы. С. } 259 \text { (по летописному } \\
\text { сборнику } 1698 \text { г., БАН. } 33.10 .5 \text { ) }\end{array}$ \\
\hline $\begin{array}{l}\text { «..Предиреченный же кн(я)зь Олегъ приимъ великое кн(я) } \\
\text { жение над словяны и русы, и нача по многимъ мъстамъ } \\
\text { грады ставити, и дани и оброки уставливати по всей Руской } \\
\text { земли. Прииде же на реку г(лаго)лемую Москву, в нея же } \\
\text { ту прилъжат двъ редъ: единой имя Неглинна, а другой Яуза, } \\
\text { и постави ту градъ немал и прозва его Москва и посади на } \\
\text { княжение от сродниковъ своих...» }\end{array}$ & $\begin{array}{l}\text { «...По смерти великаго новгородскаго князя } \text { Рюрика }_{\text {остася по нем сын его Игорь в дозоре Олгови, вельможе, }} \\
\text { сродникови своему... } \\
\text { Вышеупомянутый Олгъ, имея в дозорстве князя Игоря, } \\
\text { облада странами многими по всей земли Российстей. При } \\
\text { княжении же своем Олгъ прииде на Москву реку, в я } \\
\text { же текутъ Неглинна да Яуза, и постави ту град и нарече } \\
\text { Москва, и посади ту князя, сродника своего, и ины многи } \\
\text { грады постави во странах российских...» }\end{array}$ \\
\hline
\end{tabular}

В варианте Хронографа Олег выставлен князем, и, когда сообџается о «поставлении» им Москвы, говорится, что он там «посади на княжение» «от сродников своих». Логичным и естественным образом князь определяет «на княжение» кого-то из своих родственников, тоже обладаюшего княжеским статусом. Эта логика нарушается в варианте, опубликованном М. А. Салминой: вначале Олег выставлен лишь «вельможей», а не князем, зато далее, в сообшении об основании Москвы, говорится уже, что это происходило «при княжении» Олега и что он «посади» в Москве некоего «князя, сродника своего», то есть Олег выступает в качестве полноџенного князя. При очевидном текстуальном родстве двух вариантов во втором наблюдается смысловое несоответствие. Учитывая, что первый вариант происходит из более раннего памятника (1649-1650 г.), надо думать, что именно он и был первичен, а второй вариант представляет собой редакторскую переделку: автор взял главное сообщение об основании Москвы Олегом, но вставил его в повествовательный контекст, где Олег фигурировал не в качестве князя, а только знатного человека, хотя и породненного каким-то образом с правящей династией.

Как и предполагала М. А. Салмина, вариант статьи с Олегом-«вельможей» возник, видимо, в летописной традиџии, в основе которой лежало древнее новгородское летописание (возможно, именно в летописном сборнике, составленном в 1698 г.). Как известно, эта традиџия была весьма развита в конџе XVII в. [Азбелев].

Вариант с Олегом- «князем» был, вполне вероятно, результатом творчества самого Пахомия. Во всяком случае, в редакџии Русского хронографа «1620 г.» (дата условна, см.: [Творогов, с. 189]), на которую опирался Пахомий, легенды об основании Москвы еше не было. Русская история со времен Рюрика, Олега и Игоря излагалась в этом хронографе по «Степенной книге», где Олег, вслед за ПВЛ, выступал в качестве полноџенного князя ${ }^{8}$. Пахомий, излагая собственно русскую историю, тоже опирался на «Степенную книгу», так что определение им Олега как князя было вполне естественно.

Хронограф, который составил Пахомий, отличался от других редакџий не только тем, что в его составе появилась статья 6388 г. об основании Москвы Олегом, но и другими новаџиями. В частности, весьма сушественным для всей летописно-хронографической литературы XVII в. оказалась произведенная Пахомием вставка в «русскую часть» Хронографа сочинения, известного в науке как «Сказание о Словене и Русе».

Это сочинение, созданное в 1620-1630-е годы, вероятно, в Новгороде и бытовавшее как отдельно, так и в составе летописей, содержит фантастический рассказ об истории древних славян, часть которых под предводительством Словена и Руса заселили область вокруг озера Ильмень и реки Волхова и основали Новгород9. Автор, с одной стороны, явно отталкивался от каких-то местных новгородских преданий и сказаний с топонимическими объяснениями, а с другой - опирался на известную легенду о Чехе, Лехе и Русе и какие-то польские хроники (возможно, «Хронику» Бельского) [Мыльников, с. 141 и след.]. Главной џелью автора «Сказания о Словене и Русе» было «встроить» в общеславянский контекст историю Руси и Новгорода и показать ее древность и независимость от каких-либо внешних влияний и миграџий: русь - это славянское население Восточной Европы, обосновавшееся здесь задолго до всяких варягов, у руси издавна были свои «русские владетели», они получили подтверждение на власть еше от самого Александра Македонского и т. д.

8 Степенная книга џарского родословия по древнейшим спискам. Тексты и комментарии. В трех томах / Отв. ред. Н. Н. Покровский, Г. Д. Ленхофф. М., 2007. Т. 1. С. 151, 223.

${ }^{9}$ См. текст по Никаноровской летописи: ПСРЛ. М.-ᄉ., 1962. Т. 27. С. 137-141. 
Таким образом, статья 6388 г. и «Сказание» оказались вместе в составе Хронографа Пахомия, став частями

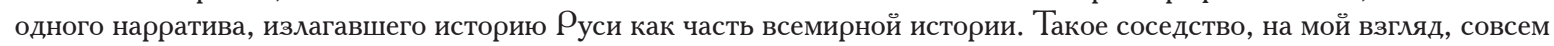
не случайно и отражает важные тенденџии в русской историографии XVII в.

Содержательно основной смысл статьи 6388 г. - удревнить историю Москвы и доказать, что город был основан в ту же эпоху, когда џентрами Руси стали Новгород и Киев. Выходило, что при «князе» Олеге были объединены под властью одной династии, которой предстояло великое будушее, не два (как говорилось в традиџии с ПВЛ), а три города. Москва тем самым практически не уступала в древности и первенстве Новгороду и Киеву. Конечно, в этом утверждении можно увидеть некоторое политическое содержание в условиях сближения России и Малороссии в середине XVII в. И при этом скорее надо думать не о 60-х годах, а о конџе 40-х годов, когда, собственно, запорожские казаки стали проситься в русское подданство, а может быть, даже и о более раннем времени (если считать, что Пахомий не сочинил статью 6388 г., а использовал созданный уже ранее текст).

Однако какими бы политическими мотивами ни руководствовался автор легенды об основании Москвы Олегом, с точки зрения истории обшественного сознания и обшественной мысли гораздо важнее отражение в этой легенде того поиска «своей истории», который считают характерным для раннемодерных наџиональных историографий [Доронин, с. 29-38]. Имеется в виду отказ от провиденџиальной и династической перспектив в понимании собственной истории, сопровождавшийся перемеџением акџента на независимое и самобытное происхождение народа.

Как и в «Сказании о Словене и Русе», в легенде об основании Москвы в IX в. проглядывает то же стремление зафиксировать глубокие автохтонные корни «мест памяти» и других опорных точек наџиональной идентичности, которая начала формироваться в после-Смутную эпоху (см. подробнее: [Стефанович, в печати]). Если до «Сказания» русская история начиналась с призвания варягов и принятия христианства от Византии, то это сочинение открывало предысторию славян, в особенности восточных славян, разворачивавшуюся задолго до варягов и греков и совершенно независимо от них. Если до «Предания» и «Повести о зачале Москвы» (которая, как теперь выясняется, была ему практически современной) древнейшая история Москвы мало интересовала русских книжников и писателей, то теперь этот факт прошлого рассматривался как важный элемент самоутверждения в настояшем на фоне других народов, выдвигавших свои исторические достижения и претензии. В «Повести о зачале Москвы» эта мысль выражена эксплиџитно в введении, где автор оправдывает обращение к прошлому города как необходимое для легитимаџии его современного державного статуса, в котором сомневаются «нђџыи от окрестных странъ», «враждующие» и «поносящие» «Москву-град» ${ }^{10}$. В легенде об основании Москвы при Олеге эта же мысль заложена имплиџитно.

Если обратиться к русской историографии до середины XVII в., мы увидим, что сам вопрос о «зачале» Москвы вообще не ставился. Впервые в древнерусской историографической традиџии только в «Степенной книге» (1560-е годы) специально выделено первое упоминание Москвы при Юрии Долгоруком. Однако ее авторов интересовал не сам по себе город Москва, а обоснование в нем «богоизбранной» династии (потомков Владимира Святого) или, по их словам, переход «прьвоначальственого скипетродръжания благочестиваго џарьствиа» из Киева во Владимир и оттуда в Москву, «идъже нынъ благородное ихъ съмя џарское преславно џарствуютъ» ${ }^{11}$. Причем эта преемственность мыслилась одновременно как религиозная, поскольку произошло и перемешение сакральных џенностей: именно Юрию приписано обретение главной общерусской святыни - Владимирской иконы Богоматери, которая, как тут же подчеркивалось, была перенесена из Киевской земли во Владимир только на время, а суждено ей находиться в Москве. Таким образом, династическое восхождение по «степеням» от киевских правителей к московским представлялось ипостасью некоей «иерофании» (если пользоваться термином М. Элиаде), переместившейся из Киева через Владимир на окончательное (вплоть до Страшного суда) пребывание в Москву.

Совершенно вне этой «сакрально-государственной» мифологии был интерес к древнейшей истории Москвы со стороны русских историков середины XVII в. Пахомий при составлении «русской части» Хронографа опирался на «Степенную книгу», но использовал только ее «хронологический остов», выбирая из нее сообшения о самых основных событиях династической и џерковной истории и дополняя другими данными и своими идеями, свидетельствующими о совершенно иной парадигме исторического сознания. Одним из таких дополнений было легендарное известие об основании Москвы Олегом, но были и другие: например, Пахомий проводил особую идею о передаче џарских инсигний в роду Рюриковичей (ср. об этом: [Сиренов, с. 16, 22]) или он дополнил «Сказание о Словене и Русе» несколько загадочным указанием на Ростов [Савинов, с. 85]. Исторические представления астраханского архиепископа нуждаются еше в дальнейшем исследовании (как и в џелом эволюџия Русского Хронографа в XVII в.),

но, в любом случае, очевидно, что мы имеем дело с наџиональной или, точнее, протонаџиональной историографией, предвосхишаюшей конструкџии «Синопсиса» и историков петровской эпохи.

Рассмотренное в такой перспективе, известие об основании Москвы Олегом едва ли может быть определено как «предание» - оно было не отражением какой-то устной или народной традиџии, а продуктом литературно-ученого творчества. Наиболее вероятным его автором выступает сам Пахомий, трудившиі̆ся в Астрахани, в непосредственном контакте с донскими/волжскими казаками, в 1649-1650 г., как раз тогда, когда от запорожских казаков поступило прошение о принятии их в подданство русского џаря. Текст

${ }^{10}$ Повести о начале Москвы. С. 174.

${ }^{11}$ Степенная книга џарского родословия по древнейшим спискам. Т. 1. С. 413, 416. 
этого известия (летописной статьи), хотя и краткий, заслуживает нового издания по двум выявленным его редакџиям и разным спискам, количество которых - теперь при учете хронографического контекста - надо предполагать больше, чем представлялось раньше.

Легенда об основании Москвы Олегом - показательный пример исторических конструкџий XVII в., в которых не надо видеть только «нелепые упражнения» примитивного «исторического баснословия» [Тихомиров, с. 95-96]. В этих «сказках» есть и «намек», и «урок» для современных ученых, если посмотреть на них как на ранние опыты наџиональной историографии, рожденные новой эпохой. Утверждение некоей самобытности с древними корнями, так или иначе соотносимой с историей народа (будь то в сопоставлении разных русских городов как «мест памяти» или в помещении руси в общеславянский контекст), обозначало принџипиальный разрыв с провиденџиальноэсхатологическими или династическими схемами Средневековья.

\footnotetext{
Литература

Азбелев С. Н. Новгородские летописи XVII в. Новгород, 1960.

Горский $A$. $A$. Москва и Орда. М., 2000.

Доронин A. B. Европа рубежа XV-XVI вв.: на пороге новой истории (взгляд с Запада) // Нарративы руси конџа XV середины XVIII в.: в поисках своей истории. М., 2018. С. 16-58.

Мыльников A. С. Картина славянского мира: взгляд из Восточной Европы. Этногенетические легенды, догадки, протогипотезы XVI - начала XVIII века. СПб., 1996.

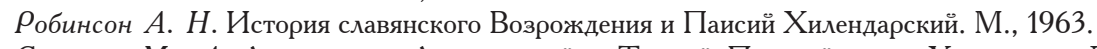

Савинов М. А. Архиепископ Астраханский и Терский Пахомий и его Хронограф. Дисс... канд. ист. наук. СПб., 2016. Сиренов А. В. Хронограф астраханского архиепископа Пахомия и Латухинская Степенная книга // Вестник РСрсИ. Гуманитарные и общественный науки. 2016. № 1 (82). С. 11-24.

Стеранович П. С. «Царствуюший град Московский»как «место памяти» в России в XVI-XVII вв. // Топография восточнославянских «мест памяти» кон. XV - сер. XVIII вв. М., 2019 (в печати).

Творогов О. В. Задачи и перспективы издания хроник и хронографов // Летописи и хроники. М., 1976. C. 189-202.

Тихомиров М. Н. Развитие исторических знаний в Киевской Руси, феодально-раздробленной Руси и Российском централизованном государстве (X-XVII вв.) // Очерки истории исторической науки в СССР. М., 1955. Т. I. С. 48-105.
}

$\rho_{\text {etr }}$ S. Stefanovich

National Research University "Higher School of Economics",

Institute of Russian History of the Russian Academy of Sciences, Moscow, Russia

THE FOUNDATION OF MOSCOW BY PRINCE OLEG AND THE CHRONOGRAPHER OF PAKHOMII

The author analyses the text known as "The Tale on the Foundation of Moscow by Oleg" after the 1964 publication by M. Salmina. He pays a special attention to the text's redaction in the "Chronographer of Pakhomii" of 1649-1650 and considers that as original. He concludes that this legendary text stressed the old and independent origins of Moscow as the city closely associated with Russian national identity and it was in the streamline of the innovative tendencies of the Russian historiography of the $17^{\text {th }}$ century.

Keywords: history, Russia, Moscow, chronicles, chronographers

УДК 94(47).04 ББК 63 DOI 10.25986/IRI.2019.75.1.0028

A. E. Тарасов

МГУ им. М. В. Ломоносова, Москва, Россия. varzuga@gmail.com

\section{БЫЛ ЛИ ЕПИСКОП ИОАСАФ ВОЛОГОДСКИЙ ИГУМЕНОМ КРАСНОХОЛМСКОГО АНТОНИЕВА МОНАСТЫРЯ?}

Статья посвящена критическому разбору гипотезы, объединяющей в одном лиџе трех деятелей Русской џеркви середины XVI в., носивших имя Иоасаф. Сделан вывод, что ряд фактов противоречит подобной интерпретаџии.

Ключевые слова: Троице-Сергиев монастырь, Краснохолмский Николаевский Антониев монастырь, Вологодская епархия,

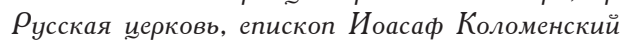

В 1883 г. отеџ Анатолий (Смирнов) сделал предположение, что игумен Краснохолмского Николаевского Антониева монастыря Иоасаф (около 1548 г.) и игумен Троиџе-Сергиева монастыря Иоасаф Черный (1555-1560 г.) - это один и тот же человек. Основанием для такого заключения стали сведения о вкладах, читаюшиеся «в описях второй половины XVI века» Краснохолмской обители, которые сделал «Троиџкой игуменъ Иасафъ» [Анатолий (Смирнов), с. 35]. С. С. Подъяпольский, не приведя никаких дополнительных аргументов, уже не сомневался в тождестве двух настоятелей [Подъяпольский, с. 29]. В 2012 г. А. В. Яганов предположил, что одно лиџо не только игумены Краснохолмского (между 1543 и 1548 г.) и Троиџе-Сергиева монастырей (с 1554 по конеџ 1559 или начало 1560 г.), но также и епископ Иоасаф Вологодский († 1570) [Яганов, с. 58-59]. Исследователь развил наблюдение о. Анатолия (Сахарова), сделав вывод, что некоторые из предметов, известных по монастырской описи 